\title{
Not Used
}

National Cancer Institute

\section{Source}

National Cancer Institute. Not Used. NCI Thesaurus. Code C69062.

Not employed or utilized. 